https://doi.org/10.21301/eap.v13i4.12

\title{
Aleksandra Nikolić
}

\author{
Central Institute for Conservation, \\ Belgrade, Serbia \\ sashnikolic@gmail.com
}

\section{Artefacts in cultural transmission: Evolutionary perspective}

\begin{abstract}
In this study, the existing body of knowledge related to the mechanisms of cultural evolution is analyzed in view of the role of artefacts in cultural transmission. It is focused primarily on the vertical transmission without inter-personal contact. Particular attention is given to the comparison between unit of culture and artefacts as its material expression, as well as to the studies of analogy between replication in genetic transmission and cultural transmission. It is found that retrieving cultural information from an artefact in absence of original transmitter still shows the principal characteristics of cultural transmission. This type of cultural transmission is of lower fidelity than synchronic transmission with inter-personal contact, since it relies on an artefact as a transmission medium, but can provide for cultural persistence and lay ground for adaptive modifications over time.
\end{abstract}

Key words: cultural transmission, artefact, material culture, cultural information, cultural evolution

Introduction

Cultural evolution theory is burdened with „dark heritage” of its own. Scientific racism reflected in XIX century evolutionist view of culture as a unilinear progressive development resulted in a decrease of interest for evolutionary approach in social sciences in the first half of the XX century, although a significant group of prominent anthropologists come out with critique and novel ideas in reaction to this concept (Degler 1992). Similarly, misinterpretation of sociobiological concept echoed across a number of disciplines concerned with human behavior and its biological basis (Segerstrale 2000).

A different period for the cultural evolution studies was initiated by arguments and evidence for Darwinian character of cultural change in the 80ies. Cavalli-Sforza and Feldman in 1981, Lumsden and Wilson in 1981, Boyd and Richerson in 1985, as well as Durham in 1991, already had available starting foundations for their theoretical models laid by scholars from various disciplinary 
background who pointed to relations and analogies between biological and cultural evolution (Gerard, Kluckhohn and Rapoport 1956; Campbell 1960; Mead 1964; Alexander 1974; Wilson 1975; Dawkins 1976; Dobzhansky et al 1977).

This was true interdisciplinary endeavor, which marked the studies following into their footsteps and leading towards the unification of cultural evolution science (Mesoudi, Whiten \& Laland, 2006). In the last two decades, a large number of studies emerged under the umbrella of cultural evolution (CE), investigating the mechanisms underlying the process and creating the possibility to compare and combine the methodologies and results of a large number of disciplines with an interest in evolutionary perspective on culture. Mesoudi and colleagues found that culture exhibits all the major Darwinian aspects, among which crucial ones would be inheritance, variation and accumulation of modifications over time: ,.... case for Darwinian cultural evolution can be made irrespective of whether unitary cultural replicators exist or whether cultural transmission mechanisms are well understood" (Mesoudi, Whiten and Laland 2004, 1).

Cultural transmission, which broadly comes down to social learning, is also referred to as cultural learning by Tomasello and colleagues (Tomasello, Kruger and Ratner 1993). It is, essentially, a process of passing cultural information between subjects which can be individuals and/or groups, thus underpinning both cultural persistence and cultural change. It happens in various forms, from imitation to deliberate teaching (Tomasello, Kruger and Ratner 1993).

Existing intra-disciplinary perspectives suggest different transmission mechanisms, but there is a general agreement on the content of cultural transmission. This impression of consensus on what is being culturally transmitted is, perhaps, simply a result of a lack of research on the subject. Apart from the studies on units of culture, which obviously tackle the transmission unit in parallel, studies of cultural transmission rarely discuss transmitted contents, and when they do it is mostly taken as a conglomerate of cultural expressions and general notions, such are values, ideas, knowledge, behavior, artefacts.

Possible pathway to look at material culture from the evolutionary point of view is the notion of extended phenotype and the Niche construction theory (NCT). Both of them put an evolving organism in the context of their eco surroundings, but while the extended phenotype was originally suggested by Richard Dawkins (Dawkins 1982) in order to explain how organism's intervention in the environment can be beneficial to genes, niche construction theory is based on the idea of reciprocity to natural selection,$- \ldots$ there are two processes in evolution, natural selection and niche construction" (Laland 2004, 324). Niche construction modifies selection pressures in the environment, thus creating eco-

${ }^{1}$ Cultural transmission predominantly happens through social learning, and many authors in the field tend to use them interchangeably. 
logical inheritance in addition to genetic inheritance in evolution (Kendal, Tehrani and Odling-Smee 2011). Niche construction theory also recognizes the critical capacity of persisting, inter-generationally transmitted cultural inheritance to affect human genetic evolution (Laland, Odling-Smee and Feldman 2001, 3). NCT is seen by some authors as a theory providing a solid general evolutionary framework, in other words - framework that could reconcile natural and social sciences (Kendal, Tehrani and Odling-Smee 2011, 7).

\section{What material culture is to culture}

As material culture is a vast field of cross-disciplinary research interests, coming not only from social sciences and humanities, but also from evolutionary biology and its sub-disciplines, defining phenomenon and its significance is expected to be complex. Except for the term ,artefacts”, which is used interchangeable with material culture in this paper and regardless of the discipline, and the term „tangible heritage”, which is, perhaps, under-used across disciplines, material culture has no direct synonyms or close enough terms. It is either genuinely seen as a disciplinary crossroads where everyone can come and have a look or contribute, or interested disciplines take it as a ready-made paradigm from where it was abundantly observed - anthropology and archaeology.

Relative abandonment of material culture studies in XX century started as a reaction to the dominance of XIX century evolutionism in early anthropology studies. The division between material and immaterial aspects of culture was popularized in the first half of XX century and stayed rather powerful even today. Nevertheless, ,despite their rhetorical elision from mainstream social anthropology, then, artefacts have never really gone away" (Chua and Salmond 2012 , 2). They were continuously used as a support material in ethnographic research. In archaeology, material culture prevails as the principal source of information throughout XX century and through all major shifts in theoretical background of the discipline. Still, the understanding of the potential and limitations of artefacts as archaeological record are seen differently in various archaeological paradigms - from historic-cultural collecting, through processual rigid scientific approach, to post-processual interpretative archaeological theory. Regardless of this general shifting of the discipline, all the major archaeological paradigms are alive today, in academy or in practice, keeping the debates around the role of material culture in past societies and knowledge construction lively and rich with new, interdisciplinary arguments.

Even though post-processual, or interpretive archaeology seemingly diverted the focus from objective to subjective understanding of the past, material culture is still much present in the late XX century archaeology theory (Hodder 
1986,1991; Tilly 1990, 1991; Shanks 1998, Shanks and Tilley 1987). The change that occurred is a change in type of instrumentality of artefacts - they have transitioned from scientific evidence to meaning bearers. This shift corresponds to the shift in other social sciences, which relativizes material culture as evidence, in accordance with human-object relations perspective. In this sense, related notions of ,symbolic storage" in cognitive processual archaeology and „external archive" (archive metaphor) in psychology denote artefacts as bearers of values and meanings which are seen as an extension to human cognition. At the same time, behavioral archaeology (Schiffer 1995), and evolutionary archaeology (Dunnell 1989) comply with other theories in focusing on human-environment relation by exploring material culture in the context of cultural evolution, even though they are not particularly interested in any content conveyed by artefacts. The shift in understanding the role and essence of material culture is reflected also in the definitions of culture, which become somewhat purely mental or ideational. As D'Andrade explains:

„Problems remain concerning the relation of cultural ideas to their physical manifestations in artifacts and actions, and a classification of the kinds of relations cultural ideas have to their physical manifestations is presented...In one sense, this is a trivial change. One just does a bit of rewording - instead of saying 'culture consists of shared ideas, shared activities, and artifacts,' one says 'culture consists of shared ideas about the world in general, ideas about how to perform certain activities, and ideas about how to make and use certain things.' However, in another sense, a profound change has taken place; culture is now a purely mental phenomenon and hence a psychological phenomenon and hence constrained by the psychological processes of cognition and learning." (D'Andrade 2001, 3)

Scholars interested in material culture have been concerned not only with its spatial aspects, but also its temporality. It is particularly the case in archaeology, where temporality is often seen as an intrinsic value of an artefact. Temporality of material culture has its basis in memory studies and cognitive psychology, relying on the concept of archive metaphor (Brockmeier 2015). This concept implies storing of mnemonic data as an input to human mind, strictly separated from its environment, but it has also an environmental analogy in so-called „external symbolic storage”, which implies material culture as a mnemonic container (Donald 1991, Renfrew 1998).

It was first a behaviorist consideration of memory as action - remembering, that considered environment in memory studies (Mori 2011, 12). Jones criticized cognitivist treatment of material culture as an external storage, but also artefacts as symbols, suggested by interpretative archaeologists, as well as behaviorists' view of artefacts as units of cultural information. He argues, instead, for the view of artefacts as "forms of mnemonic trace that have an impact on the senses" (Jones 2007, 3). This is close to what Carruthers (Carruthers 1990) finds through 
mediaeval art analysis, and to what Rowlands (Rowlands 1993, 143) sees as classical roots of Western tradition in treating artefacts as memory traces.

Obviously, material culture is of interest to a wide cluster of studies seeing culture as human intervention in the environment and technology as a means of this intervention. „The engineer should realize that his professional activities impinge upon all elements of our culture - that a bridge or telephone fulfills economic and social needs and possesses esthetic and cultural values as well as technological elements. Similarly, the social scientists and the humanists should be aware of technological influences on society and the individual, but they cannot understand these influences unless they have some knowledge of how technical devices came into being and how they function" (Kranzberg 1959, 3).

\section{Material culture and cultural evolution}

Physical space humanity occupies is characterized by human intervention. Even natural elements of our surroundings are, strictly speaking, not natural, but cultivated (Dewey 1929; Levi-Strauss 1999). So, human eco niche, a space where a human functions within an eco-system, is a cultural niche at the same time. Unlike in other species, even in other primates, it is characterized by persistence overarching a span of an individual human life. „Particularly when individuals produce enduring changes in the environment, their activities result in 'inter-generational persistence' for their social group, and thus, the traditions they will acquire. In humans, this is recognized as the cultural niche" (Fragaszy et al. 2013, 1-2). Human ecological inheritance incorporates material culture in the eco/cultural niche and niche construction relies on transmission of cultural information. „Human ecological inheritance is exceptionally potent because it includes the social transmission and inheritance of cultural knowledge, and material culture." (Kendal, Tehrani and Odling-Smee 2011,1). As it is already stated - human eco niche is a cultural niche, which further leads to recognizing ecological inheritance as cultural inheritance. Better yet, it can be identified as culture, since it involves transmission as a mechanism and cultural knowledge and material culture as the contents. Cultural knowledge is, perhaps, uncritically assigned term to denote transmitted contents, for the reasons that will be discussed further on, but material culture is attributed a major role in eco/cultural niche.

A number of scholars explored the relation between basic elements of eco/ cultural inheritance. Fragaszy and colleagues tackled the role of artefacts in transmission of culture, by introducing dimension of time in the niche construction theory, through the notion of „enduring artefacts” (Fragaszy et al. 2013). This implies a possibility to encounter enduring elements of the niche even without the agency of original transmitter. It can be referred to as ,scaffolding 
physical circumstances in favor of youngsters handling appropriate objects in appropriate contexts through provision of durable artefacts" (Fragaszy et al. 2013, 7). Clearly, scaffolding implies not simply the construction of niche and provision for survival, but a complex intergenerational transmission based on interaction with tools.

\section{The problem of replication and the unit}

Even though the replication is not crucial element for culture to perform principal evolutionary aspects, unit of culture is still the subject to the vast number of inter and intra-disciplinary studies. By analogy with biological evolution, and building upon earlier theories considered with distribution of elements of culture, Dawkins suggested that culture evolves through transmission of „memes”, which are broadly seen as cultural replicators and an analogy to genes (Dawkins 1976). The concept was further developed by Lumsden and Wilson through "culturgens", serving as a base entity for the translation from cultural to genetic evolution coupled in their dual inheritance model (Lumsden and Wilson 1981). Gabora looked for the traits of the replicators in culture and found that at most, some cultural items can show a behavior of a kind that characterizes the primitive pre-RNA replicators (Gabora 2004). Pocklington and Best pointed to the problem of seeking cultural replicators, ,without direct access to the content of human minds" and prompted instead the focus on Hull's ,interactors” (Hull 1988) or Dawkins' „vehicles” (Dawkins 1982) which can reflect the mental replicators (Pocklington and Best 1997, 2). Obviously, the question of unit of culture is not only about reflecting replicators, be them genes or mental representations, but it is also about conveying them, or rather transmitting to other conveyers. D'Andrade defined items of culture as complex cognitive molecules or schemas, chunked out of universal cognitive atoms (D'Andrade 2001, 16). This draws on the work of Anna Wierzbicka, who argued that there is a small number of universal concepts found as lexical items in all languages and that these words are conceptual primes or primitives that form the basic units from which all other concepts are constructed (Wierzbicka 1992).

The prominent cultural evolution scholars are sceptic about the direct parallels between genetic and cultural transmission too. „Cultural variation is not transmitted in the same way as genes - ideas are not poured from one head into another" (Boyd and Richerson 2005, 8). Boyd and Richerson also avoid particulate inheritance and any further specification of the nature of ,information" they choose as the base term to define culture (Boyd and Richerson 1985, 47-48).

Even though the cultural change is generally seen as cumulative in terms of series of micro-modifications building up innovations over time, replication is 
not found in this process (Sperber 1996, Sperber and Cladiere 2005, Boyd and Richerson 2005). Quite contrary, there's general agreement about various psychological factors affecting the adaptation through individual decision-making and preferences, ,each with a distinctive twist of its own and none exactly like natural selection. (Boyd and Richerson 2005, 10)

\section{Artefacts in cultural transmission}

There are numerous and diverse definitions of culture, which implies the need to specify the understanding of the notion of culture within this study. Synthetic evolutionary discourse has not yet been reached, so definitions offered by cultural evolution scholars coming from various disciplinary backgrounds is a meaningful start. Faithful to their initial, 1985 definition (Boyd and Richerson 1985, 47-48), Richerson and Boyd define culture in their 2005 book as ,information capable of affecting individuals' behavior that they acquire from other members of their species through teaching, imitation, and other forms of social transmission" (Richerson and Boyd 2005, 14). This definition contains elements that are in accordance with the subject of this study - informatological character of culture and insistence on the social process of cultural transmission by learning. Mesoudi and colleagues insist on these two critical elements of culture too, but their definition also gives example of knowledge, beliefs, and values as acquired information, and, what is more crucial for the subject of this paper, they divide cultural expressions into behavior and artefacts (Mesoudi, Whiten and Laland 2004).

In discussing the role of artefacts in cultural transmission, there's a pre-discussion need to make a distinction between ,evidence of" and the „role in”. Although material culture is abundantly treated as the evidence of cultural transmission, being primary source of information in archaeological research, it is argued here that artefacts have an idiosyncratic role in cultural transmission, even when there's no one to play the role of a transmitter. The distinction is somewhat blurred by partial overlapping of these two types of relation between artefact and transmission, but the position is critical for the perspective of the study nonetheless.

Further on, it is argued here that retrieval of information or learning from artefacts is social learning even in absence of inter and intra-generational contact between actors of the transmission process. This role of artefacts in cultural transmission depends on circumstances in which cultural information is retrieved from them. Those circumstances refer to legibility of an artefact, the way it is used or safe kept, relations with other artefacts and other elements of the same cultural niche and the meanings these relations bear. Apart from this 
more internal circumstances, transmission role of an artefact also depends on the external circumstances of information retrieval process. These are practically learning circumstances related both to the learner and the process itself, such as perception or cognitive biases.

There are clearly multiple factors affecting the information retrieval from an artefact. In accordance with what has been stated here, these factors would fall into three categories:

1. Physical state (state of preservation)

2. Context (interpretation and institutional dynamics)

3. Perceptive ability and biases of the receiver/learner

The effect of physical state of an artefact on the transmission rate has already been studied experimentally (Nikolić, Damnjanović and Cvetković 2017, while the context and psychological factors are part of an ongoing research by the same authors, aiming at creating an optimized transmission model based on the ratio between preservation and reconstruction.

Nevertheless, it is not the question here what affects the artefact-based transmission, but can artefacts provide transmission of cultural information by themselves at all and how is that possible without inter-personal contact. This has a lot to do with the character of the transmission process.

Faithful transmission of culture provides for retaining beneficial traits through generations, which is referred to as ,ratchet effect” in cumulative culture evolution in humans (Tomasello, Kruger and Ratner 1993). Since genetic transmission cannot follow the environmental changes happening today, cumulative cultural evolution takes over a significant adaptive role. In this sense, cumulative cultural evolution is described as the way in which knowledge accumulates in human populations over time, where each generation makes use of behaviors and artefacts invented by previous generations, and thus is provided with better chances to produce technological modifications. Many quantitative studies show the significance of faithful transmission (Tomasello, Kruger and Ratner 1993; Whiten and Erdal 2012; Lewis and Laland 2012). Lewis and Laland explain how long-lasting culture allows for more modifications and recombinations, and consequently allows for the ratchet effect (Lewis and Laland 2012).

This is opposed by some authors insisting on reconstructive character of cultural transmission. In fact, there is an ongoing discussion about the essential features of cultural transmission among scholars (Acerbi and Mesoudi 2015), and it is centered around the question whether it is a preservative or transformative process. Sperber and Cladiere argue that cultural transmission is, essentially, a process of transformation, where individuals re-create cultural variances and 
where persistence is not provided through fidelity, but through stable „cultural attractors" (Sperber and Cladiere 2008). Still, it seems rightfully concluded by Acerbi and Mesoudi that the character of cultural transmission will depend on the study focus, the unit of transmission and the clarity of the transmitted technology (Acerbi and Mesoudi 2015). So, what if the focus is on artefacts and the unit is as abstract as cultural information (or take knowledge, for example!) related to a complex technology?

In aforementioned definition by Mesoudi and colleagues, culture is expressed through artefacts and behaviors, but these are very different phenomena. Importance of structuralist dichotomy for the difference between physical and ideational element in an object becomes more apparent and relevant in informatological distinction between vehicle or carrier, signifier, content and the signified (Tuđman 1983), as well as in a medium and a message in communicology (Debray 2004). There's also an evident distinction between transmitting behaviors and transmitting artefacts. While the later cannot be described as any kind of activity between transmitter and receiver (apart from a grandparent literally handing over a piece of family treasure to his successor), behaviors are traits that can be learned, through imitation or teaching.

Cultural information or trait can take a form of an artefact as a vehicle/bearer or a medium in transmission. This means that an artefact is not a transmitted object, but rather means of transmission. An artefact can be produced in a process which is at the same time a demonstration of a transmitted behavior. The role of an artefact in such a transmission process is minimized - there is an inter-subjective contact and a behavior is transmitted directly between individuals. Slightly more independent is the role of an artefacts in inter-personal transmission where a person is using it to illustrate orally transmitted information. This is similar to the situation in which behavior is preserved through re-enacting - there is still a transmitter present. In the lack of inter-personal contact, which is an inter-generational contact in vertical transmission, artefacts become the sole source of cultural information, and even defining it as a source is questionable, since retrieval of information depends on many factors around the actor.

In recent years, there have been some studies in cultural evolution that tackle the role of artefacts in transmission as a secondary element in experimental simulation (Caldwell 2008a; Caldwell 2008b) or within field research, such as temporally enduring artefacts in primates. They already open up the question how important is fidelity for cultural persistence:

„Fidelity of copying the actions of another is not the basis for the persistence of technical traditions. Rather, features of the physical properties of the tools and of the tool activities that promote persistent practice in the absence of reinforcement hold the key to the development of technical traditions that require expert" (Fragaszy et al. 2013, 7). 
This understanding of artefacts as parallel or surrogate source of cultural information can also be found in Sperber and Cladiere: „Cultural information spreads across members of a population through their interactions, that is, through their producing, in their common environment, events and objects that carry information that others can pick up" (Sperbere and Cladiere 2008, 2). An interaction with artefacts is obviously seen as a type of cultural transmission, regardless of the views of the character of cultural transmission.

Transmission through artefacts assumes a particular learning modality. In contemporary learning theories, this is referred to as object-based learning (Duhs 2011; Hannan, Chatterjee, and Duhs 2013). Keene explains how „Understanding the elements of how people think helps to explain why objects could be useful in education. Different types of sensory input are processed in different parts of the brain. Multiple sensory inputs - sight, hearing, touch, and feel - are particularly valuable in learning, and objects can provide these" (Keene 2006, 68). Object-based learning is defined and primarily studied in the context of formal education. Following aforementioned lab and field studies on the artefacts as secondary source of cultural information, it can be concluded, contrary to Tomasello's arguments, that inter-subjectivity is not a prerequisite to cultural transmission, but rather a facilitation element (Gabora 2004). So object-based learning can be seen as social learning mechanism as well. Heyes defined social learning as ,learning that is influenced by observation of, or interaction with, another animal (typically a conspecific) or its products" (Heyes 1994, 1). It is possible that Tomasello doesn't take into account such an indirect transmission mechanism, because he focuses on ontogenesis in theory of cultural learning, and it is not typical for ontogenesis to lack human interaction. Either way, cultural transmission doesn't necessarily assume socialization in terms of direct contact between individuals - it can also rely on learning from social context which can also be understood as cultural and eco niche. To put it simply - object-based learning is social because objects are social, since they belong to cultivated human environment, which is a complex system of relations between humans and things (Latour 1996; Latour 1999; Law 1999).

The question of the type of role that artefact plays in cultural transmission takes the discussion back to the issue of unit of culture, transmission unit and search for a replicator in cultural evolution. There are numerous ideas there that seem to be reflecting on the artefacts as well. Are they memetic vehicles, symbolic archives, memory triggers or media?

Richerson and Boyd define culture as information, considering it mostly a mental category, but they also state that artefacts bear cultural information" (Richerson and Boyd 2005, 61). Sperber \& Cladiere ask if cultural information is located in people's mind/brain or in their behaviors and artefacts, or in both (Sperber and Cladiere 2008). Indeed, mental representations are crucial for 
culture. Sperber\&Cladiere put it simply: „No mind - no culture” (Sperber and Cladiere 2008, 2). Dawkins argue that physical manifestations of culture are to mental representations what phenotype is to genes (Dawkins 1976; Dawkins 1982), introducing a certain hierarchy between these two cultural classes. On the other hand, D'Andrade's cognitive atoms are chunked into so many different kinds of cognitive molecules of varying size and complexity, that cultural items are extremely difficult to classify (D'Andrade 2001). Even so,

„....cultural ideas/meanings/knowledge/understandings are always fused to physical manifestations. Just as language needs both meaning and sound, so culture needs both ideas and physical manifestations. It would be odd if linguists decided to define language as just meanings and to treat the sounds of speech as something else entirely" (D’Andrade 2001, 9).

Defining physical manifestation of a trait as a vehicle in transmission comes also from Richard Dawkins and it refers, actually, to phenotype as the vehicle for genes (Dawkins 1982). Lianne Gabora, though, finds no argument to see any cultural trait as a replicator, except in a primitive pre-RNA form. Not only cultural traits have no self-replication instructions, they also transform in transmission (Gabora 2004, 5; Sperber and Cladiere 2008, 6).

Difference between a vehicle and a medium is in the level of activity. While a vehicle implies an action, a medium is more of a state. Mediological view would opt for media as a key player not only in communication, but also in transmission (Debray 2004). Contrary to the semiotics, informatology not only gives attention to the material aspects of information, but also distinguishes between physical bearer (or vehicle) of a sign, and a medium. According to Miroslav Tuđman, physical bearer of a message is just one of the elements of a message, while a medium includes a sign together with its contents (Tuđman 1983). In terms of cultural unit expression, vehicle conveys ideas and meanings, and medium enables an interaction between transmitter and receiver. The difference is even clearer in terms of replication. Should ideas be seen as memes or any kind of replicator, then artefacts could serve as conveyers or vehicles driving ideas from one mind to another. From the perspective of Gabora's theory of worldview as a replicator (Gabora 2004), an artefact is indeed a more static phenomenon of an external archive, which serves as cognitive prosthetics and enables replication through interaction and exchange of ideas between worldviews or cognitive structures. Since an artefact is not transmitted (neither it is a transmitter!), but enables transmission, it can be seen as medium, similarly as it cannot be taken as heritage itself but rather its material expression.

„Houses, furniture, cars, clothing, and so on-the artifacts of culture-are hierarchically complex arrangements of items. If these artifacts were not present to learn about, we would not be able to conceive of them" (D'Andrade 2001, 5). 
Being diachronic, vertical, inter-generational transmission is, obviously, strongly affected by the factor of time. Andrew Jones' critique of behaviorists' concept of memes and the notion of symbolic storage in cognitive and interpretative archaeology targets the absence of memory from the artefact-in-the-transmission equation. He argues that material culture plays the role of a memory trigger through interaction between an individual and an artefact (Jones 2007). Perhaps this argument can be reconciled with the concepts of external symbolic storage in culture through Rowlands' idea of duplicity of artefact's role in transmission - for him, not only that it is informative in the sense of technological information, but it is also evocative (Rowlands 1993, 144).

What is achieved particularly by diachronic artefact-based transmission is cultural persistence which is a prerequisite to evolution-driving modifications. Persistence is achieved through transmission as a process and in cultural niche as a physical context. Object-based learning can play a surrogate of a direct cultural transmission where there is no inter or intra-generational contact. Cultural niche with material culture is a major resource for such a transmission process. Cultural niche provides for a variety of cultural traits, which allows for cross-fertilization and combination (Lewis and Laland 2012, 2172), and ,increased existence times of accurately transmitted cultural traits could result in more opportunity for modifications or combinations to occur (Enquist et al. 2010, 1361). „Cultural traits have to exist for long enough within the population for modifications to occur and to be combined with other traits in order for cumulative culture to develop..." (Lewis and Laland 2012, 2172).

\section{Conclusions}

Diachronic transmission is particularly low-fidelity, because, being indirect, it relies solely on media. Lack of inter-generational contact drives it already closer to the reconstruction pole, but the opportunity for multi-sensory interaction with artefacts keeps it on the track of preservation.

Ellen states that the point of discussion about artefacts and transmission is not about an artefact being replicated, but rather about a lasting cultural model which allows for flexibility in expression of cultural ideas, values and behaviors (Ellen 2009). It actually means that there's still replication, but on the level of cultural information, and not on the level of artefact, which corresponds with Gabora's theory of the worldview as a replicator (Gabora 2004). Similarly, Acerbi and Mesoudi give an example of reproducing lasagna at home after tasting it at friend's house, which, again, relativizes fidelity as a prerequisite in transmission (Acerbi and Mesoudi 2015, 494). 
Where there is no inter-generational contact, ideas are transmitted with more or less fidelity via their more or less preserved material expressions. In terms of learning process, this corresponds to the learner-centered constructivist approach, where learners ,,build on their existing understanding and knowledge by selecting information and inputs from the environment around them" (Keene 2006, 67). The knowledge, or the collective awareness of ideas, which can also be seen as values, is based on interpretation which is basically reconstruction of these cultural elements. „The lives of artefacts in the present are not half as exciting as those they had in the past. And yet, those past lives are direct outcome of their present lives" (Holtorf 2002, 16). Gabora states that, already on individual level, idea is subjected to ,something akin to interpretation when it is transmitted to and contemplated or reflected upon by a new individual". She, then, relies on Piaget in explaining how this process of interpretation is rooted in mutual transformation of transmitted information and already existing worldview or a mindset, and she calls this assimilation /accommodation processes (Gabora 2004, 5). Interpretation is seen also by Sperber and Cladiere as one of the two critical parts of learning process, which is an essence of cultural transmission:

„The information contained in the behaviors and artifacts through which culture is transmitted is quite generally insufficient to determine by itself the contents of the corresponding mental representations. In order to exploit this information, learners must bring to bear on it not only general learning or imitation skills, but also domain-specific information and procedures already present in their minds...The learning process involves not just extraction but also interpretation of input information, and interpretation typically involves enrichment of the information interpreted" (Sperber and Cladiere 2005, 7).

Reflecting this theory on cultural transmission via artefacts, it becomes clear that they provide for an assimilation/accommodation process somewhere on the preservation-reconstruction continuum. Where exactly - will depend heavily on the transmission unit in terms that more complex the cultural information, the more reconstructive the transmission (Acerbi and Mesoudi 2015, 496). If the decision-making forces, or psychological forces according to Sperber and Cladiere (Sperber and Cladiere 2005, 6), are one of the driving factors of cultural evolution, this is where not only biases, but also interpretation comes in. With addition of ecological forces as yet another category of forces acting on culture (Sperber and Cladiere 2005), there's all the more reason to take artefacts as one of the key drivers of cultural transmission, even if they don't provide for high fidelity in the process. 


\section{References}

Acerbi, Alberto, and Alex Mesoudi. 2015. If we are all cultural Darwinians what's the fuss about? Clarifying recent disagreements in the field of cultural evolution. Biology \& philosophy 30 (4): 481-503. DOI 10.1007/s10539-015-9490-2

Alexander, Richard D. 1974. The evolution of social behavior. Annual review of ecology and systematics 5 (1): 325-383.

Boyd, Robert, and Peter J. Richerson. 1985. Culture and the Evolutionary Process. Chicago: University of Chicago Press.

Boyd, Robert, and Peter J. Richerson. 2005. „Culture, Adaptation, and Innateness”. In the Innate Mind: Volume 2: Culture and Cognition, ed. Peter Carruthers, Stephen Laurence, Stephen Stich, 23-38. New York: Oxford Univ. Press.

Brockmeier, Jens. 2015. Beyond the archive: Memory, narrative, and the autobiographical process. Oxford, UK: Oxford University Press.

Caldwell, Christine A., and Ailsa E. Millen. 2008a. Experimental models for testing hypotheses about cumulative cultural evolution. Evolution and Human Behavior 29 (3): $165-171$. DOI: $10.1177 / 0963721416641049$

---. 2008b. Studying cumulative cultural evolution in the laboratory. Philosophical Transactions of the Royal Society B: Biological Sciences 363, no. 1509: 3529-3539. http://www.jstor.org/stable/20208768 (Accessed: 25/07/2014)

Campbell, Donald T. 1960. Blind variation and selective retentions in creative thought as in other knowledge processes. Psychological review 67 (6): 380-400.

Carruthers, Mary J. 1990. The book of memory: A study of memory in medieval culture. Cambridge: Cambridge University Press.

Cavalli-Sforza, Luigi Luca, and Marcus W. Feldman. 1981. Cultural transmission and evolution: a quantitative approach. New Jersey: Princeton University Press.

Chua, Liana and Amiria Salmond. 2012. „Artefacts in Anthropology”. In the SAGE Handbook of Social Anthropology, 101-114. London: SAGE Publications Ltd.

D'Andrade, Roy. 2001. A cognitivist's view of the units debate in cultural anthropology. Cross-cultural research 35 (2): 242-257. DOI: 10.1177/106939710103500208

Dawkins, Richard. 1976. The Selfish Gene. Oxford, UK: Oxford University Press.

---. 1982. The Extended Phenotype. Oxford, UK: Freeman.

Debray, Régis. 2004. Transmitting culture. New York: Columbia University Press.

Degler, Carl N. 1992. In search of human nature: The decline and revival of Darwinism in American social thought. Oxford, UK: Oxford University Press on Demand.

Dewey, John. 1929. Experience and nature. London: George Allen and Unwin Ltd.

Dobzhansky, Theodosius, F. J. Ayala, G. Ledyard Stebbins, J. W. Valentine. 1977. Evolution. San Francisco: Freeman. DOI: 10.4135/9781446201077.n42.

Donald, Merlin. 1991. Origins of the modern mind: Three stages in the evolution of culture and cognition. Cambridge, MA: Harvard University Press.

Duhs, Rosalind. 2010. Learning from university museums and collections in higher education: University College London (UCL). University Museums and Collections Journal 3: 183-186. https://pdfs.semanticscholar.org/56ff/25ab546bb362b1f262ad1 eee86fa793969e4.pdf 
Dunnell, Robert C. 1989. Aspects of the application of evolutionary theory in archaeology. Archaeological thought in America: 35-49.

Ellen, Roy. 2009. A modular approach to understanding the transmission of technical knowledge: Nuaulu basket-making from Seram, eastern Indonesia. Journal of Material Culture 14 (2): 243-277. https://doi.org/10.1177/1359183509103065

Enquist, Magnus, P. Strimling, K. Eriksson, K. Laland, and J. Sjostrand. 2010. One cultural parent makes no culture. Animal Behaviour 79 (6): 1353-1362. https://doi. org/10.1016/j.anbehav.2010.03.009

Fragaszy, Dorothy M., D. Biro, Y. Eshchar, T. Humle, P. Izar, B. Resende, and E. Visalberghi. 2013. The fourth dimension of tool use: temporally enduring artefacts aid primates learning to use tools. Philosophical Transactions: Biological Sciences 368 (1630): 1-10. http://www.jstor.org/stable/42569293.

Gabora, Liane. 2004. Ideas Are Not Replicators but Minds Are. Biology \& Philosophy 19 (1): 127-43. https://doi.org/10.1023/B:BIPH.0000013234.87103.76.

Gerard, Ralph W., Clyde Kluckhohn and Anatol Rapoport. 1956. Biological and cultural evolution some analogies and explorations. Behavioral Science 1 (1): 6-34.

Hannan, Leonie, Helen Chatterjee, and Rosalind Duhs. 2013. „Object based learning: a powerful pedagogy for higher education." In Museums and higher education working together: challenges and opportunities, eds. Speight Catherine, Jos Boys, and Anne Boddington, 159-168. Farnham: Ashgate Publishing, Ltd.

Heyes, Cecilia M. 1994. Social learning in animals: categories and mechanisms. Biological Reviews 69 (2): 207-231. https://onlinelibrary.wiley.com/doi/10.1111/j.1469-185X.1994.tb01506.x

Hodder, Ian. 1986. Reading the Past: Current Approaches to Interpretation in Archaeology. Cambridge: Cambridge University Press.

---. 1991. Interpretive archaeology and its role. American antiquity 56 (1): 7-18. Stable URL: https://www.jstor.org/stable/280968 (Accessed: 22-11-2018)

Holtorf, Cornelius. 2002. Notes on the life history of a pot sherd. Journal of material culture 7 (1): 49-71. DOI: 10.1177/1359183502007001305

Hull, David L. 1988. „Interactors versus vehicles.” In The role of behavior in evolution, ed. Henry C. Plotkin, 19-50. Cambridge, MA: Massachusetts Institute of Technology.

Jones, Andrew. 2007. Memory and material culture. Cambridge, UK: Cambridge University Press.

Keene, Suzanne. 2006. Fragments of the world: Uses of museum collections. Abingdon-on-Thames: Routledge.

Kendal, Jeremy, Jamshid J. Tehrani, and John Odling-Smee. 2011. Human niche construction in interdisciplinary focus. Philosophical Transactions of the Royal Society B: Biological Sciences 366 (1566): 785-92. DOI: 10.1098/rstb.2010.0306

Kranzberg, Melvin. 1959. At the start. Technology and Culture 1(1): 1-10.

Laland, Kevin N. Extending the extended phenotype. 2004. Biology and Philosophy 19

(3): 313-325. https://doi.org/10.1023/B:BIPH.0000036113.38737.d8

Latour, Bruno. 1996. On Actor-network Theory: A Few Clarifications. Soziale Welt 47 (4): 369-81. http://www.jstor.org/stable/40878163 (Accessed 6/02/2015).

Latour, Bruno. 1999. On Recalling Ant. The Sociological Review 47 (1))_suppl: 15-25. DOI:10.1111/j.1467-954X.1999.tb03480.x. 
Law, John. 1999. After ANT: Complexity, naming and topology. The Sociological Review 47 (1)_suppl: 1-14. DOI:10.1111/j.1467-954X.1999.tb03479.x.

Levi-Strauss, Claude, 1999. Tužni tropi. Translated by Slavica Miletić. Belgrade: Zepter book world.

Lewis, Hannah M., and Kevin N. Laland. 2012. Transmission fidelity is the key to the build-up of cumulative culture. Philosophical Transactions of the Royal Society B: Biological Sciences 367 (1599): 2171-2180. DOI: 10.1098/rstb.2012.0119

Lumsden Charles J. and Edward. O. Wilson. 1981. Genes, Mind and Culture. Cambridge, MA: Harvard University Press.

Mead, Margaret. 2017. Continuities in cultural evolution. Abingdon: Routledge.

Mesoudi, Alex, Andrew Whiten, and Kevin N. Laland. 2004. Perspective: Is human cultural evolution Darwinian? Evidence reviewed from the perspective of The Origin of Species. Evolution 58 (1): 1-11. https://www.jstor.org/stable/3449291 (Accessed 11/05/2017)

Mesoudi, Alex, Andrew Whiten, and Kevin N. Laland. 2006. Towards a unified science of cultural evolution. Behavioral and Brain Sciences 29 (4): 329-347. https://doi. org/10.1017/S0140525X06009083

Mori, Naohisa. 2011. Where are we going beyond the archive metaphor? Culture \& Psychology 17 (1): 11-19. DOI: 10.1177/1354067X10388855

Nikolić, Aleksandra, Kaja Damjanović, Dragana Cvetković. 2017. „Evolutionary perspective on tangible cultural heritage: artefacts as social learning modality". Paper presented at the Inaugural Conference of the Cultural Evolution Society, Jena, September 13-15.

Pocklington, Richard, and Michael L. Best. 1997. Cultural evolution and units of selection in replicating text. Journal of Theoretical Biology 188 (1): 79-87. https://doi. org/10.1006/jtbi.1997.0460

Renfrew, Colin. 1998. „Mind and matter: cognitive archaeology and external symbolic storage." In Cognition and material culture: the archaeology of symbolic storage, eds. Colin Renfrew and Chris Scarre, 1-6. Cambridge: McDonald Institute for Archaeological Research.

Richerson, Peter and Robert Boyd. 2005. Not by Genes Alone: How Culture Transformed Human Evolution. Chicago: University of Chicago Press.

Rowlands, Michael. 1993. The role of memory in the transmission of culture. World archaeology 25 (2): 141-151. https://www.jstor.org/stable/124810

Schiffer, Michael B. 1995. „Social theory and history in behavioral archaeology.” Expanding archaeology, eds. James M. Skibo, William H. Walker and Axel E. Nielsen, 22-35. Salt Lake City: University of Utah Press.

Segestrale, Ullica. 2000. Defenders of the Truth: The Battle for Science in the Sociobiology Debate and Beyond. New York: Oxford University Press.

Shanks, Michael, and Christopher Y. Tilley. 1987. Social theory and archaeology. Cambridge, UK: Polity Press.

Shanks, Michael. 1998. The life of an artifact in an interpretive archaeology. Fennoscandia Archaeologica XV: 15-30. http://webcache.googleusercontent.com/search?q=cache:http://www.sarks.fi/fa/PDF/FA15_15.pdf 
Sperber, Dan, and Nicolas Claidière. 2008. Defining and explaining culture (comments on Richerson and Boyd, Not by genes alone). Biology \& Philosophy 23 (2): 283292. https://doi.org/10.1007/s10539-005-9012-8

Sperber, Dan. 1996. Explaining culture: A naturalistic approach. Oxford, UK: Blackwell. Tilley, Christopher (ed.) 1990. Reading Material Culture. Oxford: Blackwell.

---. 1991. Material Culture and Text: The Art of Ambiguity. Abingdon: Routledge.

Tomasello, Michael, Ann Cale Kruger, and Hilary Horn Ratner. 1993. Cultural learning. Behavioral and brain sciences 16 (3): 495-511. https://doi.org/10.1017/ S0140525X0003123X

Tuđman, Miroslav. 1983. Struktura kulturne informacije. Zagreb: Zavod za kulturu Hrvatske. Whiten, Andrew, and David Erdal. 2012. The human socio-cognitive niche and its evolutionary origins. Philosophical Transactions of the Royal Society B: Biological Sciences 367, no. 1599: 2119-2129. DOI: 10.1098/rstb.2012.0114

Wierzbicka, Anna. 1992. Semantics, culture, and cognition: Universal human concepts in culture-specific configurations. Oxford, UK: Oxford University Press on Demand.

Aleksandra Nikolić Centralni institut za konzervaciju, Beograd

Artefakti u kulturnoj transmisiji: evoluciona perspektiva

U ovoj studji postojeći veliki opseg znanja povezan sa mehanizmima kulturne evolucije, analiziran je kroz perspektivu uloge artefakata u kulturnoj transmisiji. Usredsređenost je prvenstveno na vertikalnoj transmisiji bez međuljudskog kontakta. Posebna pažnja poklanja se poređenju jedinice kulture i artefakata kao njenog materijalnog izražaja, kao i studijama analogije između replikacije u genetskoj transmisiji i kulturne transmisije. Utvrđeno je da prikupljanje kulturnih informacija iz artefakata, u odustvu originalnog prenosioca, i dalje pokazuje ključne karakteristike kulturne transmisije. Ovaj tip kulturne transmisije manje je pouzdan od sinhronijske transmisije sa međuljudskim kontaktom, budući da se oslanja na artefakt kao medijum transmisije, ali može da omogući kulturno istrajavanje i planiranje adaptivnih promena tokom vremena.

Ključne reči: kulturna transmisija, artefakt, materijalna kultura, kulturna informacija, kulturna evolucija

\section{Les artefacts dans la transmission culturelle: perspective évolutionnaire}

Dans cette étude l'ensemble actuel de connaissances se rapportant aux mécanismes de l'évolution culturelle est analysé à travers la perspective du rôle des artefacts dans la transmission culturelle. L'étude est principalement concentrée sur la transmission verticale sans contact interpersonnel. Une attention 
particulière est portée à la comparaison entre l'unité de culture et les artefacts, expression matérielle de cette culture, tout comme à l'étude d'analogies entre la réplication dans la transmission génétique et la transmission culturelle. Il a été établi que le recueil d'informations culturelles à partir des artefacts dans l'absence de transmetteur original continue à contenir les caractéristiques clé de la transmission culturelle. Ce type de transmission culturelle est moins fiable que la transmission synchronique avec contact interpersonnel, étant donné qu'elle s'appuie sur un artefact comme médium de transmission, mais peut assurer la persistance culturelle et offrir une base pour des changements adaptatifs au cours du temps.

Mots clés: transmission culturelle, artefact, culture matérielle, information culturelle, information culturelle, évolution culturelle

Primljeno / Received: 15.06.2018.

Prihvaćeno / Accepted: 26.11.2018. 